\title{
Piperidine nucleus in the field of drug discovery
}

\author{
Mennatallah Mahmoud Abdelshaheed ${ }^{1}$, Iten Mamdouh Fawzy² ${ }^{2}$ Hussein Ibrahim El-Subbagh ${ }^{3}$ and \\ Khairia Mohamed Youssef ${ }^{2^{*}}$ (D)
}

\begin{abstract}
Background: Piperidine is an essential heterocyclic system and a pivotal cornerstone in the production of drugs. Piperidine byproducts showed several important pharmacophoric features and are being utilized in different therapeutic applications.
\end{abstract}

Main text: Piperidine derivatives are being utilized in different ways as anticancer, antiviral, antimalarial, antimicrobial, antifungal, antihypertension, analgesic, anti-inflammatory, anti-Alzheimer, antipsychotic and/or anticoagulant agents.

Conclusions: This review article sheds a light on the most recent studies proving the importance of piperidine nucleus in the field of drug discovery.

Keywords: Piperidine, Naturally occurring piperidines, Piperidine derivatives as anticancer agents, Piperidine derivatives as antivirals

\section{Background}

Heterocyclic compounds, Mainly those bearing Nitrogen are ubiquitous in nature and in medicaments as well. Most of them play important roles in the human body and have great biologic qualities.

Piperidine (Hexahydropyridine) (Fig. 1) is an organic heterocyclic amine widely used as a building block and reagent in synthesizing organic compounds, Including medicinal products [1].

Piperidine derivatives represent a key and extensive category of Nitrogen bearing heterocyclic compounds. Compounds with piperidine moiety show a wide variety of biologic activities. Piperidine is a vital fundament in the production of drugs. This nitrogen bearing heterocyclic ring system and its byproducts show several essential features and are being utilized in different ways as anticancer, antimicrobial, analgesic, antiinflammatory, and

\footnotetext{
*Correspondence: kyoussef@fue.edu.eg

2 Department of Pharmaceutical Chemistry, Faculty of Pharmaceutical Sciences and Pharmaceutical Industries, Future University in Egypt, Cairo 12311, Egypt

Full list of author information is available at the end of the article
}

antipsychotic agents. Piperidine and pyridine complexes comprehend two of the most common heterocyclic fragments present in FDA approved drugs [2].
Main text
Naturally occurring piperidine-based compounds
Piperine (N-acylpiperidine) (Fig. 2) is a true alkaloid hav- ing piperidine moiety, found in plants of Piperaceae fam- ily; it shows powerful antioxidant action because of its capability of hindering or suppressing free radicals. The pharmaceutical worth of Piperine is extensive because of its activity against cancer, inflammation, hypertension, and asthma [3]. Piperine was also found to have anti- depressant like effects when given to mice with chronic mild stress [4]. On the other hand, the mechanism of action of Piperine is still not totally clear [5].
Nobuji et al. obtained diverse phenolic amides from pepper; those compounds showed reassuring anti-oxi- dation qualities in different assays. All of the amides dis- played a positive antioxidation effect [6].
Several piperidine alkaloids isolated from natural herbs, were found to exhibit antiproliferation and anti- metastatic effects on various types of cancers both 
<smiles>C1CCNCC1</smiles>

Structure of piperidine moiety

Fig. 1 Structure of piperidine moiety<smiles>O=C(/C=C/C=C/c1ccc2c(c1)OCO2)N1CCCCC1</smiles>

Structure of Piperine

Fig. 2 Structure of piperine

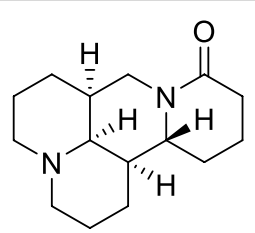

Structure of Matrine

Fig. 3 Structure of matrine<smiles>COc1ccc2cc3c(cc2c1OC)[N+]1=CCc2cc4c(cc2C=C1C4)OCO3</smiles>

Structure of Berberine

Fig. 4 Structure of berberine

in vitro and in vivo for example Piperine (Fig. 2), Evodiamine (Fig. 8), Matrine (Fig. 3), Berberine (Fig. 4) and Tetrandine (Fig. 5) [7].

\section{Piperidine derivatives as anticancer agents}

Cancer, uncontrolled cell growth, is a worldwide health matter that impacts a major proportion of the human population. These three malignant properties of cancer differentiate them from benign tumors, which are self-limited, do not invade or metastasize [8]. Cancer treatments have developed through recent years. Cancer treatments now include surgery, chemotherapy, radiotherapy, and modern approaches, namely

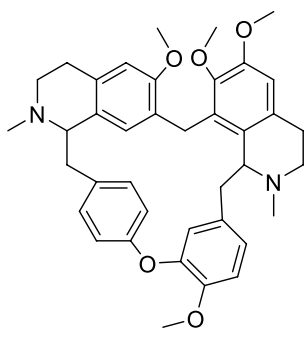

Structure of Tetrandine

Fig. 5 Structure of tetrandine

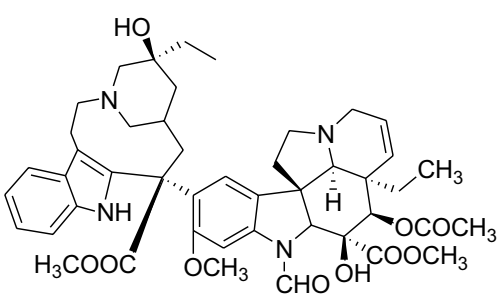

Structure of Vinblastine

Fig. 6 Structure of vinblastine

interventional radiology, hormone therapy, and immunotherapy [9]. Anticancer medicines are categorized into groups according to their mechanism of action into alkylating agents, antimetabolites, anti-tumor antibiotics, topoisomerase inhibitors, and microtubule binding agents [10]. There are more than one hundred medically approved chemotherapeutic medications [11]. However, the toxicological data of most anticancer drugs have restrained their medicinal application as antiproliferative agents $[10,12]$. In spite of the great achievements made in chemotherapy in recent years, resistance to conventional chemotherapeutic drugs and new targeted therapeutic agents is still a significant issue in cancer treatments and the cause of most recurrences [12-16]. Therefore, research of new anticancer agents with new mechanisms of action, high potency and low side effects is essential for chemists [8]. To diminish anticancer drugs' adverse effects upon normal cells, targeted cancer therapies are favored nowadays [17]. Targeted drugs block the growth and proliferation of cancer by interfering with specific molecules that are involved in the rise, advancement, and expansion of cancer without affecting normal cells [17]. Some chemotherapeutic agents have piperidine moiety within their structure, foremost among them, vinblastine and raloxifene.

Vinblastine (Fig. 6) is a plant alkaloid which is extracted from Vinca Rosea. This drug is an antineoplastic agent. 


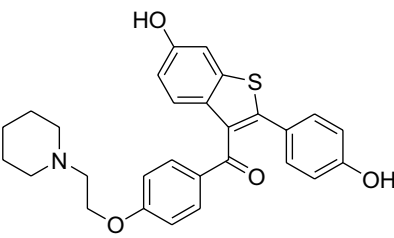

Structure of Raloxifene

Fig. 7 Structure of raloxifene

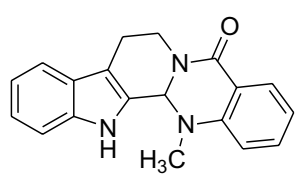

Structure of Evodiamine

Fig. 8 Structure of evodiamine

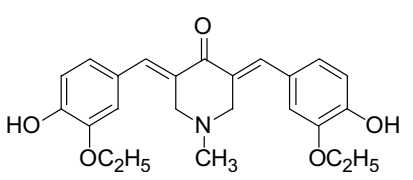

(1)

Structure of N-methyl-4-piperidone derivative

Fig. 9 Structure of $\mathrm{N}$-methyl-4-piperidone derivative

It is thought that the mechanism of action of Vinblastine is inhibition of mitosis at metaphase leading to mitotic arrest or cell death [18].

Raloxifene (Fig. 7) is second-generation selective estrogen receptor modulator (SERM). It is used for reducing the risk of invasive breast carcinoma in postmenopausal women by acting as estrogen blocker [19].

Evodiamine (Fig. 8) which is a quinolone alkaloid isolated from Evodia rutaecarpa was found to show anticancer effects in vivo and in vitro by induction of apoptosis or cell cycle arrest therefore preventing metastasis and angiogenesis [20-22].

Khairia et al. synthesized two piperidine analogues. These analogues were evaluated for their chemo preventive effect. Compound 1 (Fig. 9) was found to be the most potent chemo-preventive agent and could successfully decrease the number of cancer cells [23].

Suvankar et al. studied a series of twenty-five piperidine derivatives as free radical scavengers. These compounds exhibited a potent anticancer effect. Compound 2 (Fig. 10) was found to be the most potent antitumor agent. The mechanism of action was found to be binding to ctDNA via intercalation [24].<smiles>COC(=O)C1=C(Nc2ccc(F)cc2)C[C@@H](c2ccc(F)cc2)N(c2ccc(F)cc2)[C@H]1c1ccc(F)cc1</smiles>

(2)

Structure of piperidine derivative

Fig. 10 Structure of a piperidine derivative

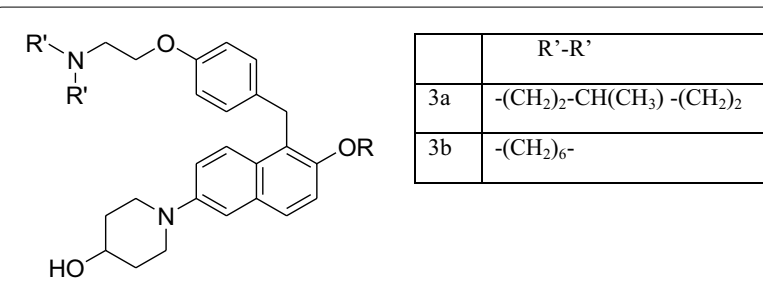

(3)

Structure of hydroxypiperidine derivatives

Fig. 11 Structure of hydroxypiperidine derivatives

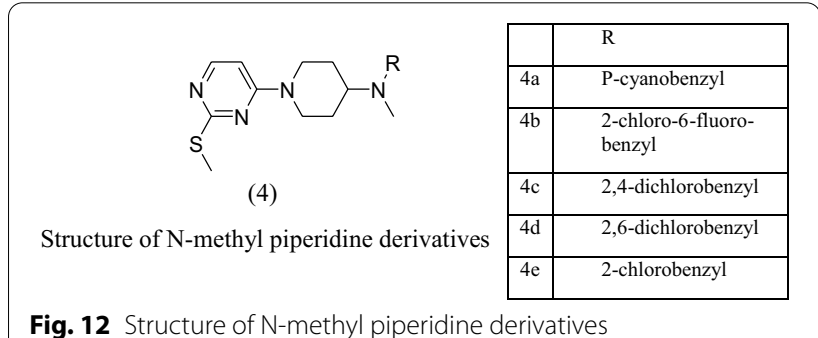

Amitabh et al. synthesized a novel series of piperidine derivatives and related aryl methyl ethers that were evaluated against MCF-7 breast cancer cell line and were found to have potent cytotoxic activity. Compounds 3a and 3b (Fig. 11) showed the highest efficiency. These compounds were tested against murine L1210, human HeLa, and CEM cell lines and demonstrated greater activity than both tamoxifen and raloxifene [25].

Yanqun et al. designed and synthesized a string of piperidine derivatives as new HSP70 inhibitors based on virtual library screening. Among these, compounds $4 a-4 e$ (Fig. 12) showed remarkable inhibitory effect on human breast cancer cells [26]. 
<smiles>O=C(NC1CCN(Cc2c(F)cccc2F)CC1)c1ccc(Oc2ccccc2)cc1</smiles>

(5)

Structure of N-(piperidine-4-yl) benzamide derivatives

Fig. 13 Structure of $\mathrm{N}$-(piperidine-4-yl) benzamide derivatives<smiles>COc1ccc(CN(C(=O)CN2C(=O)CCCC2=O)c2cc(OC)c(OC)c(OC)c2)cc1</smiles>

(6)

Structure of Dioxopiperidin-1-yl derivative

Fig. 14 Structure of dioxopiperidin-1-yl derivative

Jin et al. synthesized a series of $N$-(piperidine-4-yl) benzamide compounds and investigated their effect against cancer cells. Structure activity relationship showed that the presence of halogen, carboxyl, nitro, or methyl groups on ring $\mathrm{B}$ increased the cytotoxicity of the Piperidine derivatives. Compound 5 (Fig. 13) was found to have the maximum potency with an $\mathrm{IC}_{50}$ value 15 -fold higher than Sorafenib [27].

Dong et al. prepared a series of new piperidine derivatives. These analogues were assessed for their anticancer activity. Compound 6 (Fig. 14) expressed strong antiproliferative activity by inhibiting the tubulin polymerization [28].

Xin et al. prepared a line of innovative 5-phenyl-Npiperidine ethanone-4,5-dihydropyrazole by products. The novel compounds were evaluated for their anticancer activity. Among these, compound 7 (Fig. 15) exhibited maximum potency against SGC-7901and MGC-803 cell lines. Structure activity relationship studies showed that Introduction of amide or nitro functional groups in place of trifluoromethyl group led to decreased anticancer activity [29].

Benaka et al. prepared a series of new diphenyl (piperidine-4-yl) methanol derivatives. These compounds were evaluated for their antiproliferative activity against HT-29, HeLa,16 MCF-7 and HepG2 cell lines via MTT assay. Compound 8 (Fig. 16) showed high cytotoxic activity against all cell lines. Structure

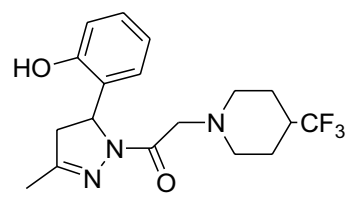

(7)

Structure of trifluoromethyl piperidine

Fig. 15 Structure of trifluoromethyl piperidine derivative

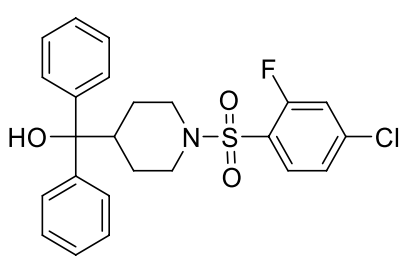

(8)

Structure of diphenyl(piperidine-4-yl) methanol derivative

Fig. 16 Structure of diphenyl(piperidine-4-yl)methanol derivative

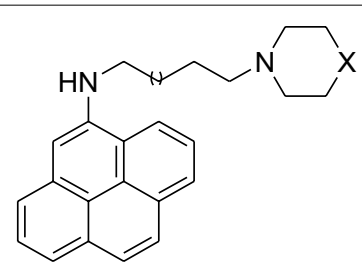

(9)

Structure of pyrenyl piperidine derivatives

Fig. 17 Structure of pyrenyl piperidine derivatives

activity relationship studies exhibited that increasing the carbon chain length reduced the antitumor activity, presence of hydrophobic groups $(\mathrm{Cl}, \mathrm{F})$ are essential for binding with the active site of the enzyme, and presence of electron donating groups $(\mathrm{Cl}, \mathrm{F})$ promotes the antitumor effect [30].

Debasish et al. synthesized a string of eight pyrenyl derivatives that were also screened for antiproliferative action. According to the $\mathrm{IC}_{50}$ data, compounds $9 \mathrm{a}$ and $9 \mathrm{~b}$ (Fig. 17) were the most potent cytotoxic agents in the string. According to structure activity relationship analysis, using four carbon linker produced higher cytotoxic effect than five carbon linker[31].

Jin et al. developed a series of novel P2X7 receptor antagonists bearing piperidine moiety as possible antitumor agents. Among them, compounds 10, 11 and 12 
<smiles>[R]N1CCN(c2cc(=O)[nH]c(=O)n2Cc2ccc(OS(=O)(=O)c3cccc4cnccc34)cc2)CC1</smiles>

(10)<smiles>[R]N1CCC(n2cncc2-c2ccc(OS(=O)(=O)c3cccc4cnccc34)cc2)CC1</smiles>

(11)<smiles>[R]OC1CCC(c2cncn2C2CCN([R])CC2)CC1</smiles>

\begin{tabular}{|l|l|}
\hline R1 & (NHCO)-PhSO2 \\
\hline R2 & $\left(4-\left(\mathrm{CH}_{3}\right) \mathrm{N}\right) \mathrm{PhCO}$ \\
\hline
\end{tabular}

(12)

Structure of 1-piperidinylimidazole derivatives

Fig. 18 Structure of 1-piperidinylimidazole derivatives

(Fig. 18) demonstrated highest cytotoxic effect against MDA-MB-231 breast cancer cell lines [32].

\section{Piperidine derivatives with antiviral activity}

Nikolai et al. synthesized a string of (R) and (S) isomers of novel adamantane-substituted piperidine analogs. Biologic tests of the produced compounds were carried out on the rimantadine-resistant S31N mutated strains of influenza A 2009(H1N1)pdm09 and modern pandemic strain 2016(H1N1)pdm09. The most powerful compounds were both enantiomers of the enol ester 13 (Fig. 19) exhibiting IC value equals to $7.7 \mu \mathrm{M}$ with the 2016 Orenburg strain [33].

Guoxin et al. performed modifications on the structure of an original compound appointed from high throughput screening. A series of different analogues were prepared and were proved to have an inhibitory effect against influenza virus. Structure-activity relationship studies indicated that the ether linkage between quinoline and piperidine is crucial to the inhibitory effect. Compound 14 (Fig. 20) showed a superb inhibitory effect on a diversity of influenza virus strains and showed a good ability to interfere with the early to middle stages of influenza virus replication[34].
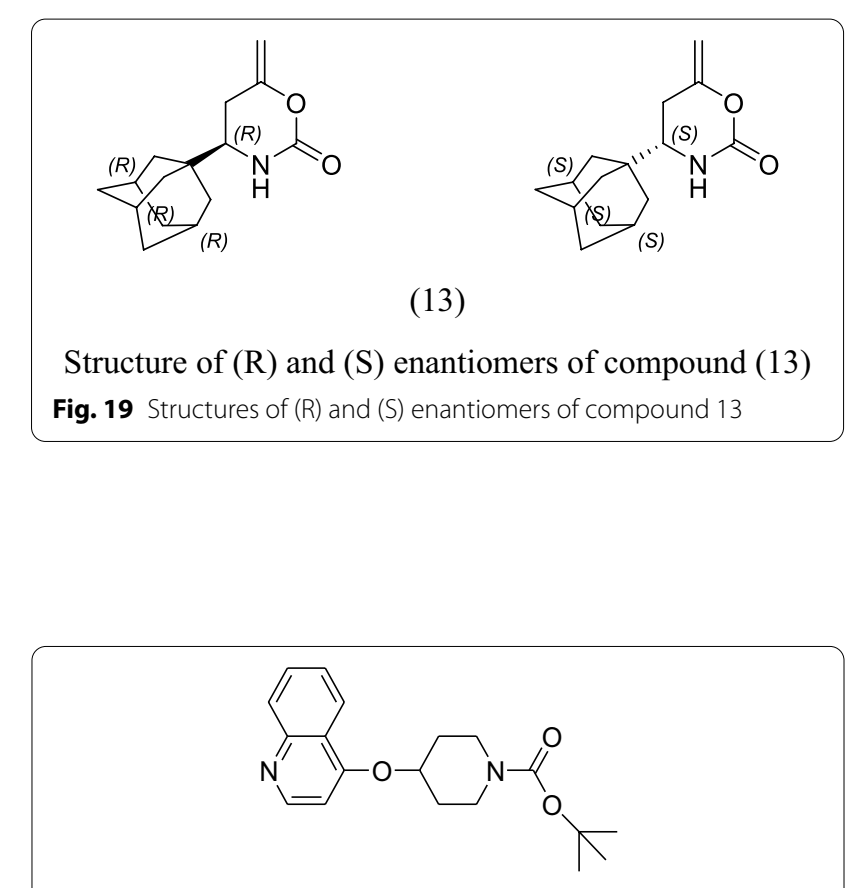

(14)

Structure of piperidine carboxylate derivative

Fig. 20 Structure of piperidine carboxylate derivative 
<smiles>OC[C@H]1NC(O)[C@@H](O)[C@H](O)[C@@H]1O</smiles>

Structure of Nojirimycin

Fig. 21 Structure of nojirimycin

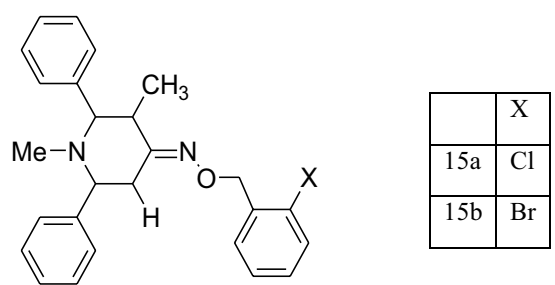

(15)

Structure of piperidine-4-one oxime derivatives

Fig. 22 Structure of piperidine-4-one oxime derivatives

\section{Piperidine derivatives with antimicrobial activity}

$\mathrm{AD}$ et al. produced two piperidine derivatives. These derivatives were isolated from Streptomyces ficellus then evaluated for their antibacterial activity. Nojirimycin (Fig. 21) was found to be effective against S. lutea, $S$. aureus and E. coli. Nojirimycin is the prototype of a new class of antibiotics [35].

Chennan et al. prepared a string of piperidine-4-one oxime derivatives that was investigated for their in vitro antimicrobial activity. Compounds $15 \mathrm{a}$ and $15 \mathrm{~b}$ (Fig. 22) exhibited strong antifungal activity against Aspergillus flavus and Candida-51, respectively. Compound 15b was found to be more effective than the reference drug; amphotericin B regarding MIC [36].

Jayaraman et al. synthesized a series of piperidone derivatives via Mannich reaction pathways. The compounds were evaluated for their antimicrobial effect against various types of bacteria and fungi. Compound 16a and 16b (Fig. 23) showed good antibacterial activity against B. subtilis, E. coli, K. pneumoniae and S. faecalis. Compound 17 and 16b (Fig. 23) showed good antifungal activity against A. niger, A flavus, C. neoformans, Candida 6 and Candida 51 [37].

\section{Piperidine derivatives with antimalarial activity}

Rokhyatou et al. designed and prepared novel 1,4 disubstituted piperidine derivatives that were tested for their

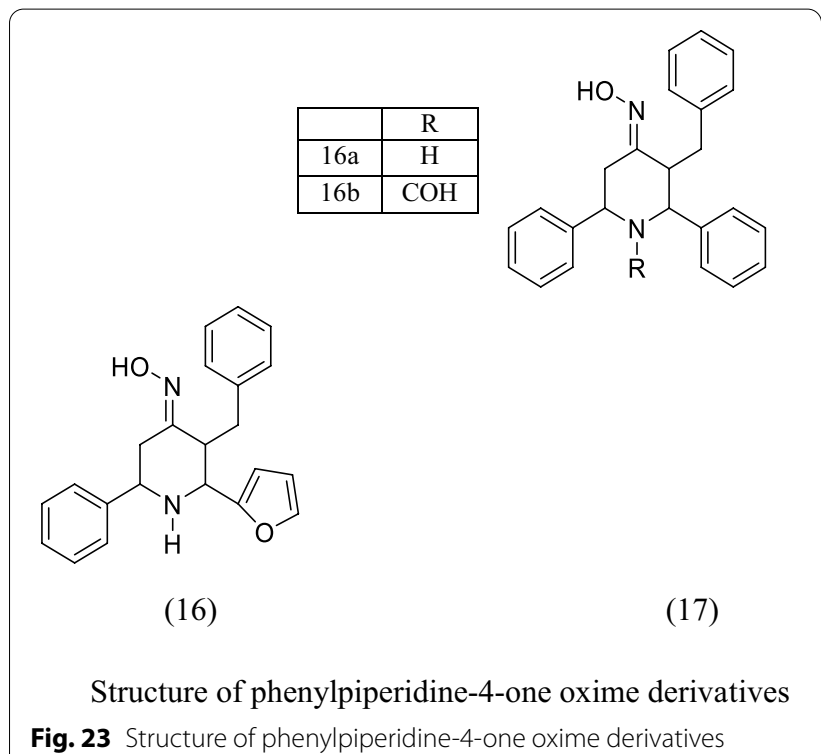

Fig. 23 Structure of phenylpiperidine-4-one oxime derivatives<smiles>[R]c1cccc(N(C(=O)COc2ccccc2[R2])C2CCN(Cc3cccc[R3]3[H])CC2)c1</smiles>

\begin{tabular}{|l|l|l|l|}
\hline & $\mathrm{R}_{1}$ & $\mathrm{R}_{2}$ & $\mathrm{R}_{3}$ \\
\hline $18 \mathrm{a}$ & $\mathrm{H}$ & $\mathrm{H}$ & $\mathrm{H}$ \\
\hline $18 \mathrm{~b}$ & $\mathrm{~F}$ & $\mathrm{Cl}$ & $\mathrm{H}$ \\
\hline $18 \mathrm{c}$ & $\mathrm{F}$ & $\mathrm{Cl}$ & $\mathrm{Br}$ \\
\hline
\end{tabular}

Structure of 1,4 disubstituted piperidine derivatives

Fig. 24 Structure of 1,4 disubstituted piperidine derivatives

activity against chloroquine sensitive and chloroquine resistant strains of $P$. falciparum. Compounds $18 \mathrm{a}-\mathrm{c}$ (Fig. 24) were the most potent compounds among the prepared library [38].

\section{Piperidine derivatives with antifungal activity}

Zhigan et al. designed and synthesized a string of new antifungal piperidinyl triazole derivatives. Multiple compounds exhibited superb antifungal activity against a range of significant fungi. Among these compounds, compounds 19 and 20 (Fig. 25) were noticed to be highly active antifungal drugs [39]. 
<smiles>OC(CN1CCC(n2cc(-c3ccc(OC(F)(F)F)cc3)nn2)CC1)(Cn1cncn1)c1ccc(F)cc1F</smiles>

(19)<smiles>CC(=O)c1ccc(-c2cn(C3CCN(CC(O)(Cn4cncn4)c4ccc(F)cc4F)CC3)nn2)cc1</smiles>

(20)

Structure of piperidinyl triazole derivatives

Fig. 25 Structure of piperidinyl triazole derivatives

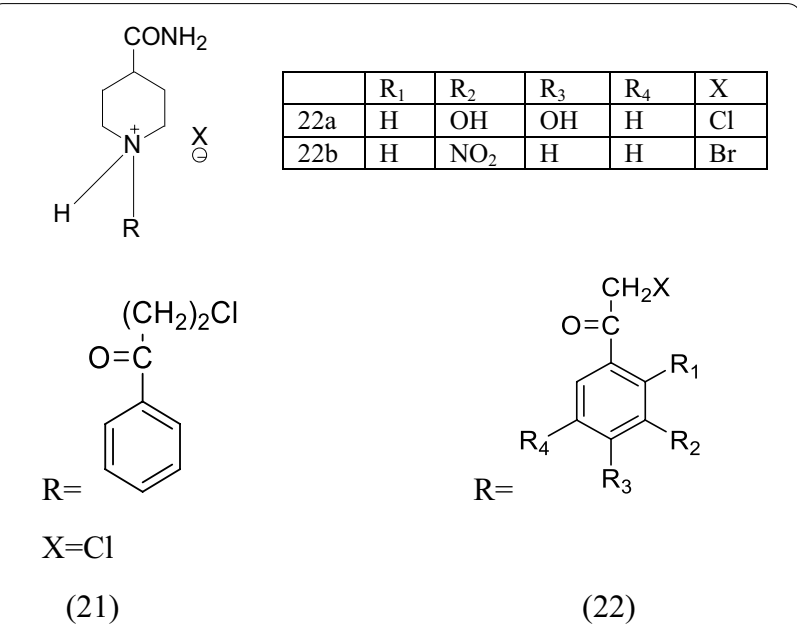

Structure of N-substituted phenacyl piperidine derivatives

Fig. 26 Structure of N-substituted phenacyl piperidine derivatives

\section{Piperdine derivatives with antihypertension activity}

Shamim et al. synthesized a string of novel N-substituted phenacyl piperidine derivatives that have been tested for their hypotensive activity. Compounds 21, 22a and 22b (Fig. 26) exhibited mild antihypertension activity. It was also discovered that the carboxamide group has no significant effects on arterial blood pressure and has no significant effect on blood pressure [40].

Yanjiang et al. tested compounds that were determined through screening of BMP2 up-regulators for their capacity to boost the expression of Inhibitor of DNA binding 1<smiles>c1ccc(-n2ncc3c(N4CCCCC4)ncnc32)cc1</smiles>

(23)

Structure of piperidinyl pyrazolo pyrimidine derivatives

Fig. 27 Structure of piperidinyl pyrazolo pyrimidine derivatives<smiles>[R]NC(=O)NC1CCN([R])CC1</smiles>

\begin{tabular}{|l|l|l|}
\hline & R1 & R \\
\hline 24 & Adamantyl & $\mathrm{COCH}_{3}$ \\
\hline
\end{tabular}

(24)

Structure of piperidinyl urea derivatives

Fig. 28 Structure of piperidinyl urea derivatives

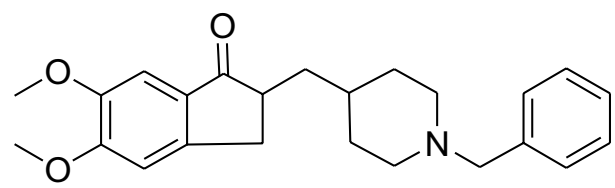

Structure of Donepezil

Fig. 29 Structure of donepezil

(ID1) proteins. Depending on stem cell technology, they produced compound 23 (Fig. 27) as BMP upregulator that regulates BMP2 and PTGS2 levels, which may be worthwhile for treating pulmonary arterial hypertension [41].

SK et al. synthesized a novel piperidinyl urea derivatives that were tested for their activity as epoxide hydrolase inhibitors. Compound 24 (Fig. 28) was found to reduce the blood pressure effictively [42].

\section{Piperidine derivatives with antiAlzheimer's activity}

Gunhild et al. studied the effect of Donepezil (Fig. 29) on the development of apathy and other neuropsychiatric disorders in patients with Alzheimer's disease. It was proved that Donepezil could cause a great reduction of apathy that reached over 6 months and thus had a considerable favourable effect [43]. 


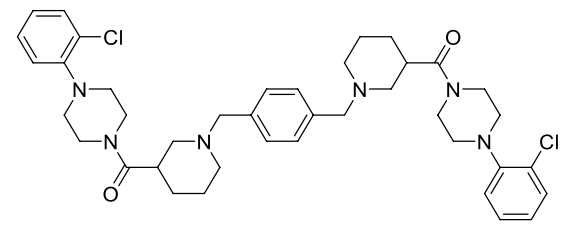

(25)

Structure of chlorophenyl piperazinyl methanone piperidine derivatives Fig. 30 Structure of chlorophenyl piperazinyl methanone piperidine derivatives<smiles>[R]C=C1CN(C)CC2(CN(C)C3(C(=O)N([R])c4ccccc43)C2[R])C1=O</smiles>

(26)

\begin{tabular}{|l|l|l|}
\hline & $\mathrm{R}$ & $\mathrm{R}^{\prime}$ \\
\hline $26 \mathrm{a}$ & $\mathrm{Ph}$ & $\mathrm{H}$ \\
\hline $26 \mathrm{~b}$ & $4-\mathrm{H}_{3} \mathrm{COC}_{6} \mathrm{H}_{4}$ & $\mathrm{H}$ \\
\hline $26 \mathrm{c}$ & 2-thienyl & $\mathrm{H}$ \\
\hline
\end{tabular}

Structure of N-methyl-4-piperidineone derivatives

Fig. 31 Structure of $\mathrm{N}$-methyl-4-piperidine-one derivatives
Khairia et al. designed and synthesized a string of novel piperidine derivatives that were evaluated for their inhibitory effect on acetylcholinesterase. These derivatives exhibited successful AchE inhibition, high selectivity and significant radical scavenging properties. Compound 25 (Fig. 30) exhibited high free radical scavenging effect [44].

\section{Piperidine derivatives with analgesic and antiinflammatory activity}

Adel prepared a series of piperidine derivatives that were tested for their antitumour activity against most of the human tumour cells. All the assessed compounds exposed significant antitumour properties against (HCT116), (T-47D), [HL-60 (TB), MOLT-4, RPMI-8226] and (PC-3) cell lines. Of all the assessed compounds, compounds 26a-c (Fig. 31) showed substantial antiinflammatory properties [45].

Ahmed et al. synthesized a line of 2,4,6-trisubstitutedquinazoline derivatives bearing piperidine moiety. These compounds were tested for analgesic and antiinflammatory activity. Of all the compounds analyzed, compounds 27b, 27c and 27d (Fig. 32) were found to have higher analgesic effect than the standard drug indomethacin. Compounds 27a, 27b, 27c, 27e, 28 and 29 (Fig. 32) displayed both analgesic and antiinflammatory effects [46].

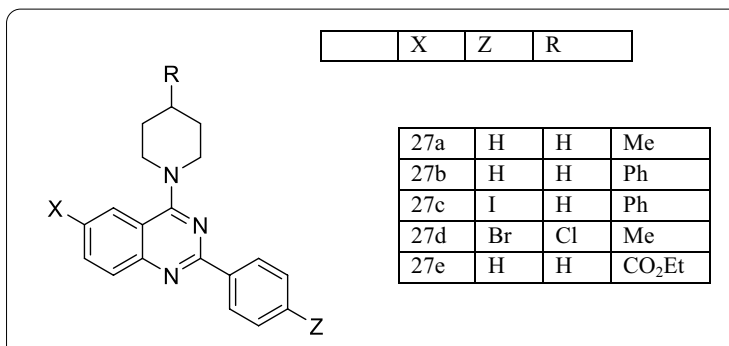

(27)<smiles>S=c1[nH]nc(C2CCN(c3nc(-c4ccccc4)nc4ccccc34)CC2)s1</smiles>

(28)

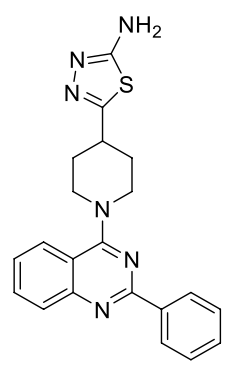

(29)
Structure of 2,4,6-trisubstituted-quinazoline piperidine derivatives

Fig. 32 Structure of 2,4,6-trisubstituted-quinazoline piperidine derivatives

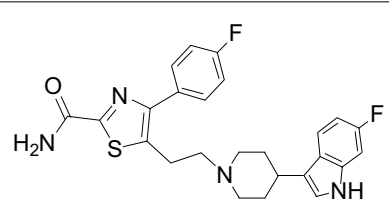

(30)

Structure of piperidinyl 6-fluoroindole derivatives

Fig. 33 Structure of piperidinyl 6-fluoroindole derivatives

\section{Piperidine derivatives with antipsychotic activity}

Takeo et al. studied and investigated the antipsychotic effect of a novel piperidine derivative. Compound 30 (Fig. 33) was observed to have affinity to several dopamine receptors and exhibited atypical antipsychotic effect in animal models with limited prevelance of extrapyramidal adverse effects [47].

Ling et al. synthesized a series of new benzoxazolepiperidine derivatives with high affinity to dopamine D2, serotonin 5-HT1A and serotonin 5HT2A receptors. Among these derivatives, compound 31 (Fig. 34) was found to be a promising antipsychotic agent [48].

Xudong et al. designed and synthesised a line of piperidine derivatives. Among them, Compound 32 (Fig. 35) showed special pharmacological properties and a worthwhile pharmacokinetic profile and exhibited pro-cognition properties. Compound 32 is thought to represent 
<smiles>Fc1ccc2c(C3CCN(CCCOc4ccc(Cc5nc6ccccc6o5)cc4)CC3)noc2c1</smiles>

Structure of benzoxazole piperidine derivatives

Fig. 34 Structure of benzoxazole piperidine derivatives<smiles>O=C(CCN1CCC(c2noc3cc(F)ccc23)CC1)c1cc2c3c(c1)CCN3C(=O)CC2</smiles>

(32)

Structure of piperidinyl fluorobenzoxazole derivatives

Fig. 35 Structure of piperidinyl fluorobenzoxazole derivatives<smiles>O=C(Nc1cccc(OCc2cccc(F)c2)c1)C1CCN(c2ccncc2)CC1</smiles>

Structure of 4-(piperidin-1-yl)pyridine derivative

Fig. 36 Structure of 4-(piperidin-1-yl)pyridine derivatives

a new class of atypical antipsychotics for schizophrenia [49].

\section{Piperidine derivatives with anticoagulant activity}

Modesto et al. synthesized a line of 4-(piperidin-1-yl)pyridine derivatives. Structure activity relationship studies revealed that compound 33 (Fig. 36) exhibited strong factor IIa inhibition and showed good anticoagulant effect [50].

Akiyoshi et al. designed, prepared and investigated two racemic piperidine diamine derivatives. Compounds 34a-e (Fig. 37) expressed great inhibitory effect on factor $\mathrm{Xa}$ and displayed a great anticoagulant activity [51].

Khairia et al. designed and prepared a series of carbamoylpyridine and carbamoylpiperidine derivatives. These derivatives were investigated for their platelet aggregation inhibition effect. Among them, compounds 35 and 36 (Fig. 38) were identified to be the most potent antiplatelet aggregation agents [52].

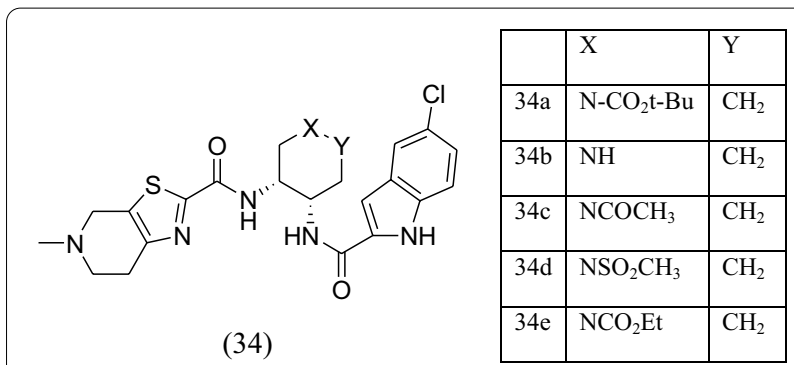

Structure of piperidine diamine derivatives

Fig. 37 Structure of piperidine diamine derivatives<smiles>O=C(C1CCCN(c2ccccc2Cl)C1)N1CCN(Cc2ccc(Br)cc2)CC1</smiles>

(35)<smiles>O=C(C1CCCN(Cc2ccc(CN3CCCC(C(=O)N4CCN(c5ccccc5Cl)CC4)C3)cc2)C1)N1CCN(c2ccccc2Cl)CC1</smiles>

(36)

Structure of carbamoyl piperidine derivatives

Fig. 38 Structure of carbamoyl piperidine derivatives

\section{Conclusions}

This review mentions the potentiality of piperidine moiety accompanied with other molecular fragments in ameliorating various disease conditions. Naturally occurring piperidines were able to display extensive effects against cancer, inflammation, hypertension and sometimes behave as antioxidants. On the other hand, Synthetic piperidine derivatives that were presented in many research studies proved their potentiality as anticancer agents, antiviral, antimicrobial, antimalarial and antifungal agents. Also, piperidine derivatives can be designed and synthesized to exhibit additional biological effects as antihypertension, antiAlzheimer's, analgesic, anti-inflammatory, antipsychotic and anticoagulant activity. 


\begin{abstract}
Abbreviations
FDA: Food and Drug Administration; SERM: Second-generation selective estrogen receptor modulator; ctDNA: Cell-free circulating tumor DNA; MCF-7: Type of breast cancer cell lines; murine L1210: Type of leukemia cancer cell lines; human HeLa: Type of cervical cancer cell lines; CEM: Type of leukemia cancer cell lines; HSP70: Heat Shock Protein Coding gene.; SGC-7901: Type of human gastric cancer cell lines: MGC-803: Type of human gastric cancer cell lines; HT-29: Type of human colorectal adeno cancer cell lines; HepG2: Type of human liver cancer cell lines; MTT: 3-(4,5-Dimethylthiazol-2-yl)-2,5-diphenyl2H-tetrazolium bromide assay; P2X7: Purinergic receptor; MDA-MB-231: Type of human breast adeno cancer cell lines; BMP: Basic Metabolic Panel; PTGS: Post-transcriptional gene silencing; AchE: Acetylcholine Esterase; MOLT-4: Type of leukemia cancer cell lines; RPMI-8226: Human myeloma cell line; PC-3: Human prostate cancer cell line.
\end{abstract}

\section{Acknowledgements}

Not applicable.

\section{Authors' contributions}

MMA collected the data and wrote the draft manuscript. IMF collected the data and wrote the draft manuscript. HIES revised the manuscript. KMY revised the manuscript and supervised the whole work. All authors read and approved the final manuscript.

\section{Funding}

Not applicable.

\section{Availability of data and material}

Data and material are available upon request.

\section{Declarations}

\section{Ethics approval and consent to participate}

Not applicable.

\section{Consent for publication}

Not applicable.

\section{Competing interests}

The authors declare that they have no competing interests.

\section{Author details}

'Department of Pharmaceutical Chemistry, Faculty of Pharmacy, Horus University in Egypt, Jadidah, Egypt. ${ }^{2}$ Department of Pharmaceutical Chemistry, Faculty of Pharmaceutical Sciences and Pharmaceutical Industries, Future University in Egypt, Cairo 12311, Egypt. ${ }^{3}$ Department of Medicinal Chemistry, Faculty of Pharmacy, Mansoura University, P.O.Box 35516, Mansoura, Egypt.

Received: 10 May 2021 Accepted: 26 August 2021

Published online: 09 September 2021

\section{References}

1. World Heritage Encyclopedia Piperidine. In: World Heritage Encyclopedia. http://self.gutenberg.org/articles/Piperidine. Accessed 10 Dec 2020

2. Vitaku E, Smith DT, Njardarson JT (2014) Analysis of the structural diversity, substitution patterns, and frequency of nitrogen heterocycles among U.S. FDA approved pharmaceuticals. J Med Chem 57:10257-10274

3. Manjusha RK, Begum S, Begum A, Bharathi K (2018) Antioxidant potential of piperidine containing compounds: a short review. Asian J Pharm Clin Res 11:66-73

4. Li S, Wang C, Wang M, Li W, Matsumoto K, Tang Y (2007) Antidepressant like effects of piperine in chronic mild stress treated mice and its possible mechanisms. Life Sci 80:1373-1381

5. de Almeida GC, Oliveira LFS, Predes D, Fokoue HH, Kuster RM, Oliveira FL, Mendes FA, Abreu JG (2020) Piperine suppresses the Wnt/ $\beta$-catenin pathway and has anti-cancer effects on colorectal cancer cells. Sci Rep 10:1-12
6. Nakatani N, Inatani R, Ohta H, Nishioka A (1986) Chemical constituents of peppers (Piper spp.) and application to food preservation: naturally occurring antioxidative compounds. Environ Health Perspect 67:135-142

7. Lu JJ, Bao JL, Chen XP, Huang M, Wang YT (2012) Alkaloids isolated from natural herbs as the anticancer agents. Evid Based Complement Altern Med 2012:1-12

8. Singhal S, Ramanathan K, Shanthi V, Rajasekaran R (2012) Development of cancer database by amalgamation of various existing database. Int J Pharm Pharm Sci 4:479-483

9. Mayo Clinic Staff (MayoClinic) Cancer treatment. https://www.mayoclinic. org/tests-procedures/cancer-treatment/about/pac-20393344. Accessed 15 Dec 2020

10. The American Cancer society medical and editorial content team. https:// www.cancer.org/treatment/treatments-and-side-effects/treatmenttypes/chemotherapy/how-chemotherapy-drugs-work.html\#written_by. Accessed 20 Dec 2020

11. Arroyo M, Berral-Gonzalez A, Bueno-Fortes S, Alonso-Lopez DDLRJ (2020) Mining drug-target associations in cancer: analysis of gene expression and drug activity correlations. Biomolecules 10:667

12. Alfarouk KO, Stock CM, Taylor S, Walsh M, Muddathir AK, Verduzco D, Bashir AHH (2015) Resistance to cancer chemotherapy: failure in drug response from ADME to P-gp. Cancer Cell Int 15:71

13. Holohan C, Van Schaeybroeck S, Longley DBJP (2013) Cancer drug resistance: an evolving paradigm. Nat Rev Cancer 13:714-726

14. Rueff JRA (2016) Cancer drug resistance: a brief overview from a genetic viewpoint. Methods Mol Biol 1395:1-18

15. Borst P (2012) Cancer drug pan-resistance: pumps, cancer stem cells, quiescence, epithelial to mesenchymal transition, blocked cell death pathways, persisters or what? Open Biol 2:120066-120066

16. Housman G, Byler S, Heerboth S, Lapinska K, Longacre M, Snyder NSS (2014) Drug resistance in cancer: an overview. Cancers (Basel) 6:1769-1792

17. Mailankody S, Prasad V (2015) Five years of cancer drug approvals: innovation, efficacy, and costs. JAMA Oncol 1(4):539-540

18. Ngan VK, Bellman K, Hill BT, Wilson L, Jordan MA (2001) Mechanism of mitotic block and inhibition of cell proliferation by the semisynthetic vinca alkaloids vinorelbine and its newer derivative vinflunine. Mol Pharmacol 60:225-232

19. Taurin S, Allen KM, Scandlyn MJ, Rosengren RJ (2013) Raloxifene reduces triple-negative breast cancer tumor growth and decreases EGFR expression. Int J Oncol 43:785-792

20. Ogasawara M, Matsubara T, Takahashi S, Saiki I, Suzuki H (2002) Antiinvasive and metastatic activities of evodi-amine. Biol Pharm Bull 25:1491-1493

21. Fei XF, Wang BX, Li TJ, Tashiro S, Minami M, Xing DJ, Ikejima T (2003) Evodiamine, a constituent of Evodiae Fructus, induces anti-proliferating effects in tumor cells. Cancer Sci 94(1):92-98

22. Zhang Y, Wu LJ, Tashiro S, Onodera S, Ikejima T (2003) Intracellular regulation of evodiamine-induced A375-S2 cell death. Biol Pharm Bull 26(11):1543-1547

23. Youssef KM, Ezzo AM, El-Sayed MI, Hazzaa AA, EL-Medany AH, Arafa M, (2015) Chemopreventive effects of curcumin analogs in DMH-induced colon cancer in albino rats model. Future J Pharm Sci 1:57-72

24. Das S, da Silva CJ, Silva MM, Dantas MDA, de Fátima Â, Góis Ruiz ALT, da Silva CM, de Carvalho JE, Santos JCC, Figueiredo IM, da Silva-Júnior EF, de Aquino TM, de Araújo-Júnior JX, Brahmachari G, Modolo LV (2018) Highly functionalized piperidines: free radical scavenging, anticancer activity, DNA interaction and correlation with biological activity. J Adv Res 9:51-61

25. Jha A, Yadav Y, Naidu AB, Rao VK, Kumar A, Parmar VS, MacDonald WJ, Too CK, Balzarini J, Barden CJ, Cameron TS (2015) Design, synthesis and bioevaluation of novel 6-(4-Hydroxypiperidino)naphthalen-2-ol-based potential selective estrogen receptor modulators for breast cancer. Eur J Med Chem 92:103-114

26. Zeng Y, Cao R, Zhang T, Li S, Zhong W (2015) Design and synthesis of piperidine derivatives as novel human heat shock protein 70 inhibitors for the treatment of drug-resistant tumors. Eur J Med Chem 97:19-31

27. Hou J, Zhao W, Huang ZN, Yang SM, Wang LJ, Jiang Y, Zhou ZS, Zheng MY, Jiang JL, Li SH, Li FN (2015) Evaluation of novel N-(piperidine-4-yl) benzamide derivatives as potential cell cycle inhibitors in HepG2 cells. Chem Biol Drug Des 86:223-231 
28. Fu DJ, Liu SM, Yang JJ, Li J (2020) Novel piperidine derivatives as colchicine binding site inhibitors induce apoptosis and inhibit epithelial-mesenchymal transition against prostate cancer PC3 cells. J Enzyme Inhib Med Chem 35:1403-1413

29. Liu XH, Li J, Shi JB, Song BAQX (2012) Design and synthesis of novel 5-phenyl-N12 piperidine ethanone containing 4, 5-dihydropyrazole derivatives as potential 13 antitumor agents. Eur J Med Chem 51:294-299

30. Prasad SB, Vinaya K, Kumar CA, Swarup S, Rangappa KS (2009) Synthesis and in vitro antiproliferative activity of diphenyl (sulphonylpiperidin-4-yl) methanol derivatives. Med Chem Res 19:220-235

31. Bandyopadhyay D, Sanchez JL, Guerrero AM, Chang FM, Granados JC, Short JD, Banik BK (2015) Design, synthesis and biological evaluation of novel pyrenyl derivatives as anticancer agents. Eur J Med Chem 89:851-862

32. Park J, Williams DR, Lee J, Lee SD, Lee JH, Ko H, Lee GE, Kim S, Lee JM, Abdelrahman A, Muller CE, Jung DW, Kim YC (2016) Potent suppressive effects of 1-piperidinylimidazole based novel P2X7 receptor antagonists on cancer cell migration and invasion. J Med Chem 59(16):7410-7430

33. Kuznetsov NY, Tikhov RM, Godovikov IA, Medvedev MG, Lyssenko KA, Burtseva El, Kirillova ES, Bubnov YN (2017) Stereoselective synthesis of novel adamantane derivatives with high potency against rimantadineresistant influenza A virus strains. Org Biomol Chem 15(15):3152-3157

34. Wang G, Chen L, Xian T, Liang Y, Zhang X, Yang Z, Luo M (2014) Discovery and SAR study of piperidine-based derivatives as novel influenza virus inhibitors. Org Biomol Chem 12:8048-8060

35. Argoudelis AD, Reusser F, Mizsak SA, Baczynskyj L (1976) Antibiotics produced by streptomyces ficellus. II. Feldamycin and nojirimycin. J Antibiot (Tokyo) 29:1007-1014

36. Ramalingan C, Park YT, Kabilan S (2006) Synthesis, stereochemistry, and antimicrobial evaluation of substituted piperidin-4-one oxime ethers. Eur J Med Chem 41:683-696

37. Jayabharathi J, Manimekalai A, Vani TC, Padmavathy M (2007) Synthesis, stereochemistry and antimicrobial evaluation of t(3)-benzyl-r(2), c(6)diarylpiperidin-4-one and its derivatives. Eur J Med Chem 42:593-605

38. Seck R, Gassama A, Cojean S, Cavé C (2020) Synthesis and antimalarial activity of 1,4-disubstituted piperidine derivatives. Molecules 25:21-26

39. Jiang Z, Gu J, Wang C, Wang S, Liu N, Jiang Y, Zhang W, Sheng C (2014) Design, synthesis and antifungal activity of novel triazole derivatives containing substituted 1,2,3-triazole-piperdine side chains. Eur J Med Chem 82:490-497

40. Zafar S, Akhtar S, Ali SI, Mushtaq N, Naeem S, Ali M (2019) Synthesis, characterization and antimicrobial activity of piperidine derivatives. J Chem Soc Pak 41:363-367

41. Xing Y, Zhao S, Wei Q, Gong S, Zhao X, Zhou F, Ai-Lamki R, Ortmann D, Du M, Pedersen R, Shang G, Si S, Morrell NW, Yang J (2018) A novel piperidine identified by stem cell-based screening attenuates pulmonary arterial hypertension by regulating BMP2 and PTGS2 levels. Eur Respir J 51(4):1702229

42. Anandan SK, Webb HK, Chen D, Wang YX, Aavula BR, Cases S, Cheng Y, Do ZN, Mehra U, Tran V, Vincelette J, Waszczuk J, White K, Wong KR, Zhang
LN, Jones PD, Hammock BD, Patel DV, Whitcomb R, Maclntyre DE, Sabry J, Gless R (2011) 1-(1-acetyl-piperidin-4-yl)-3-adamantan-1-yl-urea (AR9281) as a potent, selective, and orally available soluble epoxide hydrolase inhibitor with efficacy in rodent models of hypertension and dysglycemia. Bioorg Med Chem Lett 21(3):983-988

43. Waldemar G, Gauthier S, Jones R, Wilkinson D, Cummings J, Lopez O, Zhang R, Xu Y, Sun Y, Knox S, Richardson S, Mackell J (2011) Effect of donepezil on emergence of apathy in mild to moderate Alzheimer's disease. Int J Geriatr Psychiatry 26:150-157

44. Youssef KM, Fawzy IM, El-subbagh HI (2017) N-substituted-piperidines as novel anti-Alzheimer agents: synthesis, antioxidant activity, and molecular docking study. Future J Pharm Sci 4:1-7

45. Girgis AS (2009) Regioselective synthesis and stereochemical structure of anti-tumor active dispiro[3H-indole-3,2'-pyrrolidine-3',3"-piperidine]2(1H), $4^{\prime \prime}$-diones. Eur J Med Chem 44:1257-1264

46. Alafeefy AM, Kadi AA, Al-deeb OA, El-tahir KEH, Al-jaber NA (2010) Synthesis, analgesic and anti-inflammatory evaluation of some novel quinazoline derivatives. Eur J Med Chem 45:4947-4952

47. Funakoshi T, Chaki S, Kawashima N, Suzuki Y, Yoshikawa R, Kumagai T, Nakazato A, Kameo K, Goto M, Okuyama S (2002) In vitro and in vivo pharmacological profile of 5-[2-[4-(6-fluoro-1H-indole-3-yl)piperidin-1-yl] ethyl]-4-(4-fluorophenyl)thiazole-2-carboxylic acid amide (NRA0562), a novel and putative atypical antipsychotic. Life Sci 7(12):1371-1384

48. Huang L, Zhang W, Zhang X, Yin L, Chen B, Song J (2015) Synthesis and pharmacological evaluation of piperidine (piperazine)-substituted benzoxazole derivatives as multi-target antipsychotics. Bioorg Med Chem Lett 5(22):5299-5305

49. Cao X, Zhang Y, Chen Y, Qiu Y, Yu M, Xu X, Liu X, Liu BF, Zhang L, Zhang G (2018) Synthesis and biological evaluation of fused tricyclic heterocycle piperazine (piperidine) derivatives as potential multireceptor atypical antipsychotics. J Med Chem 61:10017-10039

50. de Candia M, Fiorella F, Lopopolo G, Carotti A, Romano MR, Lograno MD, Martel S, Carrupt PA, Belviso BD, Caliandro R, Altomare C (2013) Synthesis and biological evaluation of direct thrombin inhibitors bearing 4-(piperidin-1-yl) pyridine at the P1 position with potent anticoagulant activity. J Med Chem 56:8696-8711

51. Mochizuki A, Nakamoto Y, Naito H, Uoto K, Ohta T (2008) Design, synthesis, and biological activity of piperidine diamine derivatives as factor $\mathrm{Xa}$ inhibitor. Bioorg Med Chem Lett 18:782-787

52. Youssef KM, Al-Omar MA, El-subbagh HI, Abou-zeid LA (2011) Synthesis, antiplatelet aggregation activity, and molecular modeling study of novel substituted-piperazine analogues. Med Chem Res 20:898-911

\section{Publisher's Note}

Springer Nature remains neutral with regard to jurisdictional claims in published maps and institutional affiliations.

\section{Submit your manuscript to a SpringerOpen ${ }^{\circ}$ journal and benefit from:}

- Convenient online submission

- Rigorous peer review

- Open access: articles freely available online

- High visibility within the field

Retaining the copyright to your article

Submit your next manuscript at springeropen.com 